\title{
Near Zero-Energy Buildings in Lebanon: The Use of Emerging Technologies and Passive Architecture
}

\author{
Osama Omar \\ Faculty of Architecture, Design and Built Environment, Beirut Arab University, Beirut 1107 2809, Lebanon; \\ o.omar@bau.edu.lb
}

Received: 30 November 2019; Accepted: 21 February 2020; Published: 13 March 2020

\begin{abstract}
Architecture always aims to find solutions for problems around the world. One of the major trends at present relates to energy consumption and climate change. Construction is responsible for $18 \%$ of $\mathrm{CO}_{2}$ emissions. However, continuing to use fuel as a main source of energy consumption for economic reasons, as it is the cheapest raw material and most easily available material for most of the Arab countries, results in a negative environmental impact on the quality of life in these countries. This paper investigates a new design concept and decision-supporting tools for zero-energy buildings. Based on critical thinking as a new mechanism to create a hierarchy of designing a building, the research presents the experience of the author in teaching architecture courses for postgraduates for five years (ARCH 662: Architecture Design and Decision-Supporting Tools and Arch 663: Advanced Sustainable Architecture). The result of this research could be new methodologies that help and guide the architect in creating more zero-energy buildings in their countries. In addition, the spread of knowledge in the future generation of architects in architecture schools will mean that new designers believe in protecting and taking care of their environment, which will increase awareness of environmental issues and improve the quality of life in these countries.
\end{abstract}

Keywords: decision support; zero-energy building; energy consumption; behavior of user; passive house

\section{Introduction}

There is an urgent need to reduce domestic energy consumption, particularly due to climate change. Domestic energy policies and research have been dominated by the assumption that technological provision will linearly save energy. Conventional attempts to move away from this approach have not gone far enough, tending to still assume that technological usage is a linear outcome of an individual's rational decision-making [1].

The development of near zero-energy buildings (NZEBs) is based on four concepts. Similar concepts can be implemented at various levels and can include quantitative metrics such as energy embodied and environmental impact (Table 1). Based on the typology of the building and the climatic context, design teams must apply these four principles in order to find the most suitable measures that follow these steps or principles, which are listed below:

First: Reducing the energy demand for all newly constructed buildings. The cost of energy demand is the sum of the building's demands-space heating, space cooling, hot water in the house, electrical power, ventilation, lighting, and appliances.

Second: Improving indoor environmental quality (IEQ), allowing maximum thermal comfort and avoiding overheating. This includes air quality control through mechanical ventilation.

Third: Fixing a percentage of renewable energy demands to be covered by a renewable energy annual balance. It is also important to amend additional measures to address energy matching and storage issues. 
Fourth: Reducing the overarching value for primary energy consumption and carbon emissions per year. It is also necessary to amend additional measures to deal with energy issues related to mobility and materials [2].

Table 1. The four principles of near zero-energy buildings (NZEB) design [2].

\begin{tabular}{cccc}
\hline First NZEB Principle & Second NZEB Principle & Third NZEB Principle & Fourth NZEB Principle \\
\hline Reduce energy demand & $\begin{array}{c}\text { Improve indoor } \\
\text { environmental quality }\end{array}$ & $\begin{array}{c}\text { Provide renewable } \\
\text { energy share }\end{array}$ & $\begin{array}{c}\text { Reduce primary energy } \\
\text { and carbon emissions }\end{array}$ \\
\hline $\begin{array}{c}\text { Reduce internal loads } \\
\text { Reduce building } \\
\text { envelope loads } \\
\begin{array}{c}\text { Reduce HVAC } \\
\text { equipment energy } \\
\text { consumption }\end{array}\end{array}$ & $\begin{array}{c}\text { Set up minimum fresh } \\
\text { air per person } \\
\text { Enable Natural lighting } \\
\text { Set up a maximum } \\
\text { occupant density }\end{array}$ & $\begin{array}{c}\text { Produce energy from } \\
\text { renewable source on-site } \\
\text { Introduce renewable } \\
\text { energy delivered from } \\
\text { nearby or offsite } \\
\text { Avoide double counting }\end{array}$ & $\begin{array}{c}\text { Reduce the primary } \\
\text { energy demand } \\
\text { Reduce the carbon } \\
\text { emissions related to } \\
\text { delivered energy. }\end{array}$ \\
\hline
\end{tabular}

Before we go forward to talk about the zero-energy concept, we need to agree on the common definition for "near zero-energy buildings", which is that a NZEB produces $30 \%$ or more of its required energy through the use of on-site renewable energy [2]. The following section presents a brief review of applicable literature.

\section{Literature Review}

The introduction of "near zero-energy buildings" (NZEBs) by the Energy Performance Building Directive (EPBD) (recast) in 2010 and the 2050 carbon budget, which led to a shift in the design paradigms within the construction industry across Europe, means that new and existing buildings are expected to be energy efficient [3-5].

The basic concept behind the NZEB standard exacerbates the risk of overheating in homes under hotter weather conditions. Despite this, there is very little research and investigation regarding the issue and the potential of the wide-spread implementation of NZEB standards across Europe to compound the risk of overheating in buildings $[3,6]$.

The aim of zero-energy buildings and zero-carbon buildings is to achieve maximum efficiency resulting from the notion of resource consumption being minimized, describing this as zero-energy consumption. Global initiatives such as the United States' "2030 Challenge" or the near zero-energy target mandated by the European Energy Performance Building Directive (EPBD) aim to reduce harmful emissions from buildings. There are also international environmental scores and qualification schemes, such as Leadership in Energy and Environmental Design (LEED), Building Research Establishment Environmental Assessment Method (BREEAM), and Minergie, aimed at improving the industrial development of NZEBs [2].

The "environmental friendliness" of home appliances will be tackled in three fundamental ways: global environmental conservation (prevention of global warming and defense of the ozone layer), resource recycling (three Rs: reduction, reuse, recycling), and chemical material control (reduction of chemical use in goods and manufacturing processes that adversely affect the environment) [7].

Although there is no information specific to the NZEB design concept, a common set of rules applies to all high-performance buildings: Trias Energetica. The set of rules for Trias Energetica presents a three-step guide to high-performance building design. This three-step approach was developed under Kees Duijvstein in the Netherlands in 1979 and is considered the fundamental rule of thumb for sustainable construction design [8], as shown in Figure 1.

The three steps are:

1. Reduce the demand for energy by avoiding waste and implementing energy conservation measures (ECMs).

2. Use sustainable sources of energy instead of finite fossil fuels. 
3. Use the cleanest possible fossil energy as efficiently as possible.

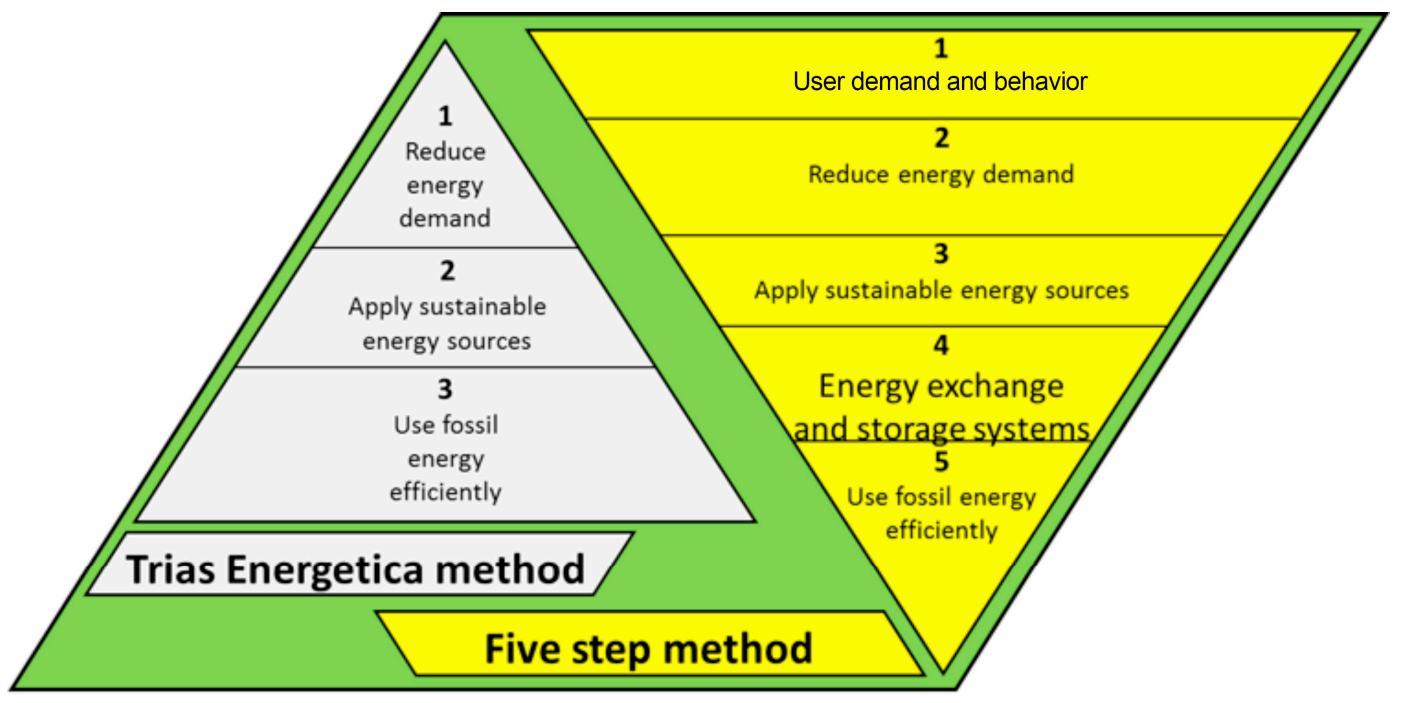

Figure 1. The fundamentals of NZEB design. Reference: [8].

Only when a building is built to reduce heat loss in heating-dominated buildings or mitigate heat gain in cooling-dominated buildings should the design team concentrate on on-site options for renewable energy, including solar or heat exchange and recovery systems. This rule highlights the importance of construction, bioclimatic design, and energy efficiency $[2,8]$.

Salem, R. et al., 2019, investigate the impacts of a changing climate on the risk of overheating and energy performance for retirement and summarize the selected energy-efficient measures (EEMs) that make up the NZEBs retrofit scenario, as in Table 2. It could be predicted that NZEBs and energy-efficient buildings are more likely to experience overheating. Their finding suggests that the incorporation of shading devices, double glazing as opposed to triple glazing, and utilizing natural ventilation are currently some of the most effective ways to mitigate the risk of overheating [9-14].

Table 2. Summary of final selected energy-efficient measures for NZEB retrofit. Reference: [14].

\begin{tabular}{cc}
\hline EEM & Design Measure \\
\hline Insulation & 180mm mineral wool insulation batts \\
\hline Lighting & LED (+ auto presence detection in communal areas) \\
\hline HVAC and DHW & $\begin{array}{c}\text { Automatic thermostat controlled direct gas fired Boiler } \\
\text { Mechanical ventilation with heat recovery in communal areas }\end{array}$ \\
\hline Microgeneration & $100 \mathrm{kWp}$ solar panel system + solar thermal collectors \\
\hline Overheating mitigating strategies & $\begin{array}{c}\text { Internal shading (vertical blinds) } \\
\text { Natural ventilation in residential areas } \\
\text { Double glazing, 36mm argon filled, Low-e }\end{array}$ \\
\hline
\end{tabular}

EEM: energy-efficient measure; DHW: domestic hot water; HVAC: Heating, ventilation, and air conditioning.

According to a 2013 study, a sophisticated analysis using "association rules" and the "a priori principle" found a strong link between cooking and watching television-when households used cooking appliances, there was a $74 \%$ chance that the television would also be on. Clear comparisons between the use of information technology (IT)-related devices (computers, screens, printers, etc.) and audio-visual devices (TVs, game consoles, etc.) were one of the predictable results. Use of the TV as a background activity for households of all grades and of new TVs with programmable auto-off times (which shut off when there is no remote control interaction) is very popular [15]. 
The Major Role of Passive Architecture Techniques:

In this area there is much terminology that can be helpful and guide the architect in their design, such as passive house (German version), low-energy buildings, vernacular architecture, etc. However, this terminology changes from country to country according to the architectural style in each country and the type of weather in each country, and from environment to environment according to which construction materials are available in each country. Some typical passive techniques are described in the following section.

Hot-dry climate: The architect should take this type of climate into their design consideration. The key is to slow the rate of indoor heating on summer days using thermal mass and shading; to promote rapid cooling on summer evenings with wind towers and/or cross ventilation; to use natural cooling in summer, with water if available; and to use natural heating in winter, so orientation and opening design for solar gain are crucial (Figure 2) [16].
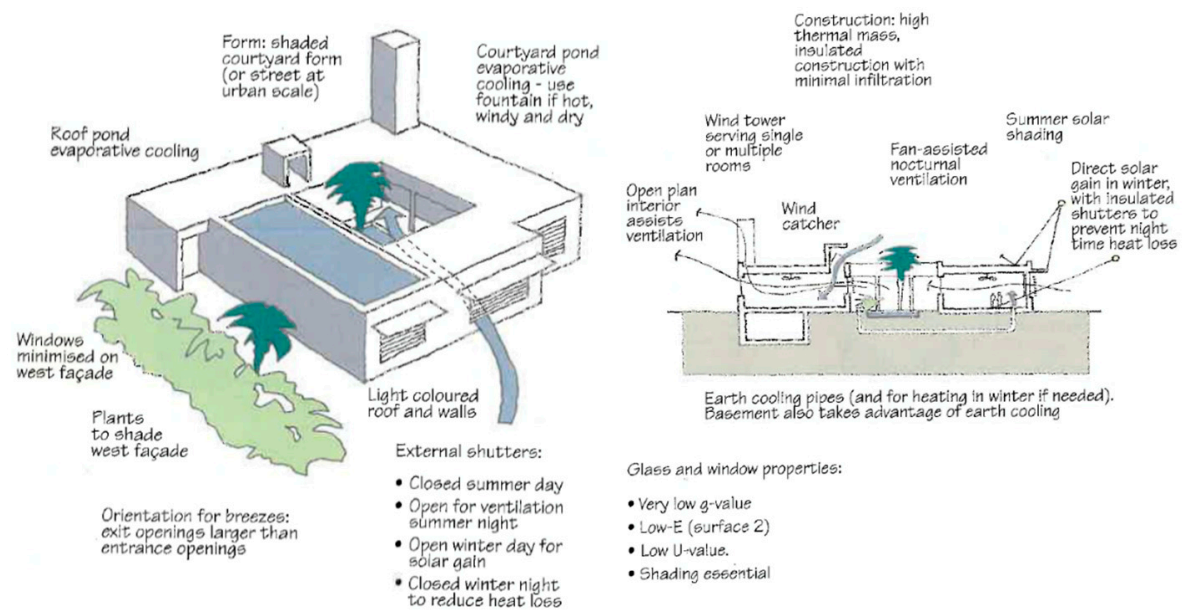

Figure 2. Passive architecture techniques in hot-dry climate. Reference: [16].

Hot-humid climate: The architect should take this type of climate into design consideration. The priority is ventilation-it must be effective, night and day. It should reduce the solar heating of the building fabric with shading; permit a high rate of evening cooling, with large openings and cross ventilation; and allow natural cooling using shaded ground, evaporative cooling, and wind (Figure 3) [16].

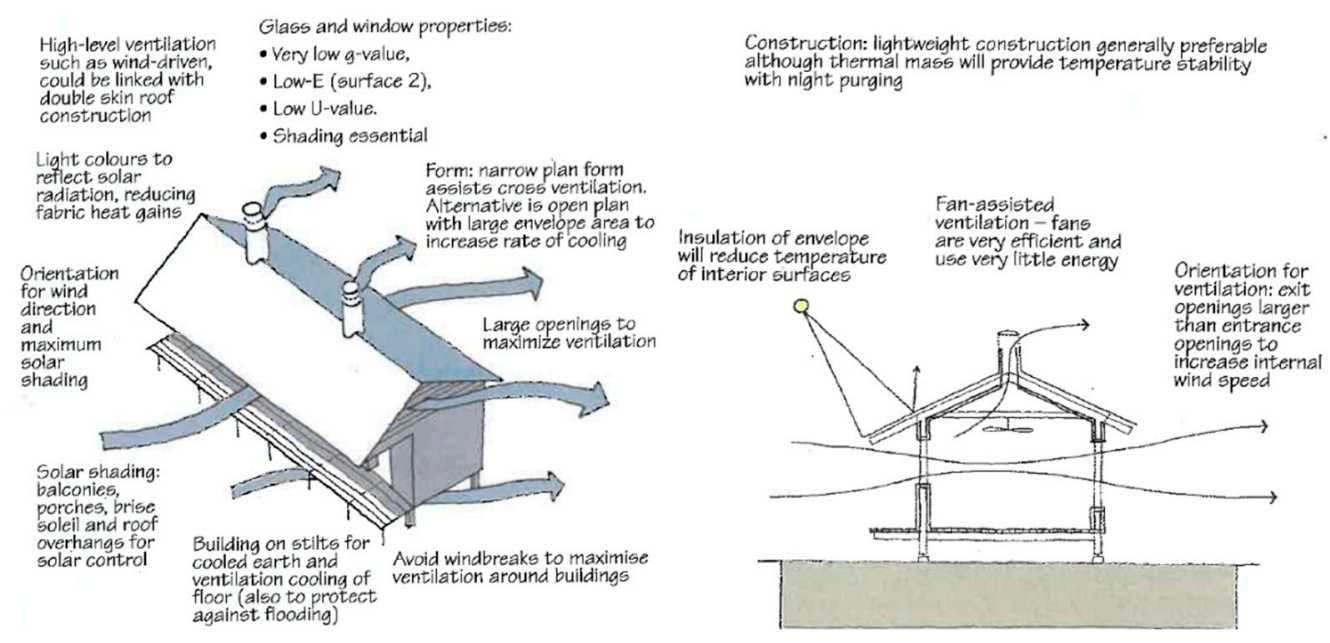

Figure 3. Passive architecture techniques in hot-humid climate. Reference: [16]. 
- Cold climate: This form of environment should be taken into consideration by the architect. The goal is to reduce the need for heating energy using buffer zones, insulation, and limited infiltration; to allow natural heating with solar gain; and to allow ventilation in the summer. Thermal super-insulation requires good ventilation to avoid overheating (Figure 4) [16].
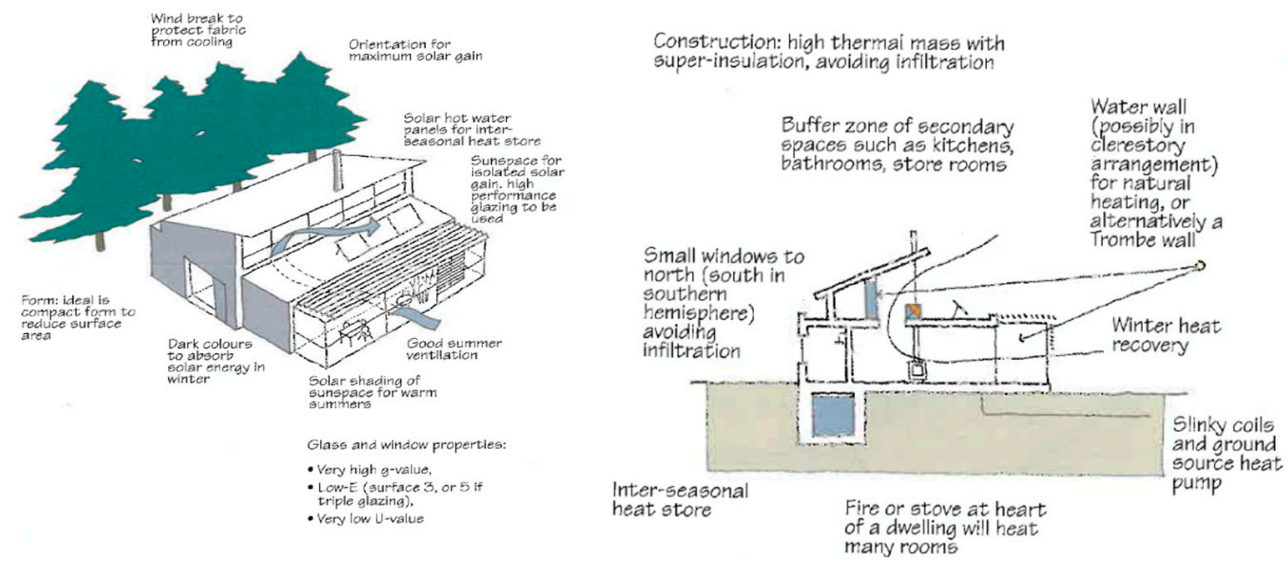

Figure 4. Passive architecture techniques in cold climate. Reference: [16].

- Cold-winter/hot-summer climate: This type of climate should be taken into account by the architect. The goal is to reduce the need for heating energy using buffer zones and isolation, along with reduced infiltration; to use natural heating and cooling with sun and wind to allow good summer ventilation, including nocturnal ventilation; and not to block summer breezes with winter windbreaks (Figure 5) [16].
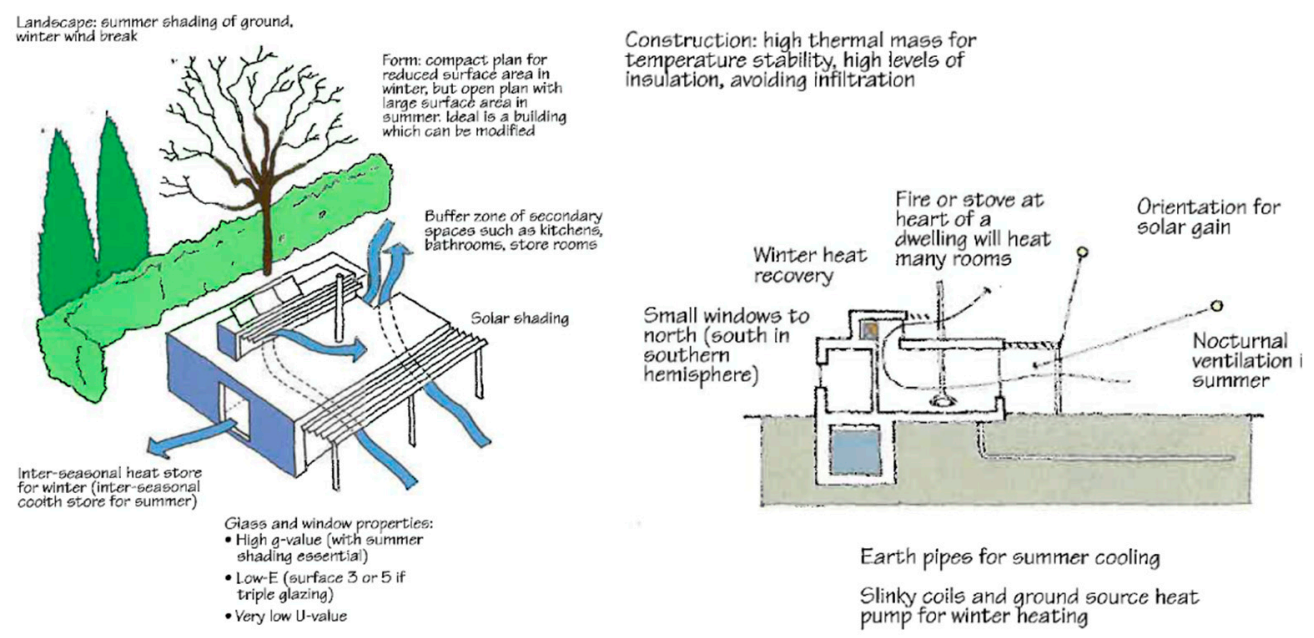

Figure 5. Passive architecture techniques in cold-winter/hot-summer climate. Reference: [16].

Temperate climate: This type of climate should be taken into consideration by the architect. The goal is to reduce the need for heating energy using buffer zones and insulation to reduce the loss of winter heat; to prevent overheating in summer with thermal mass (and nocturnal ventilation) for temperature control, with shading as necessary; and to use natural heating in winter. Reduced air infiltration is a must, so sheltered entrances and wind lobbies should be included (Figure 6) [16]. 

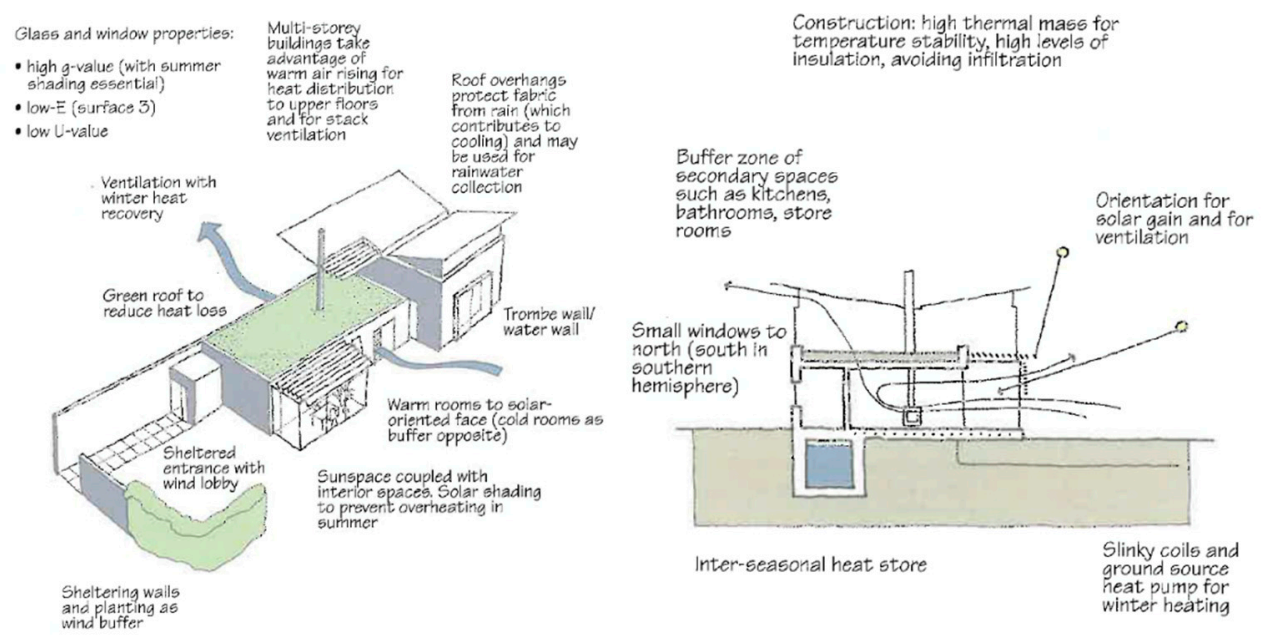

Figure 6. Passive architecture techniques in temperate climate. Reference: [16].

\section{Proposed Research to Support NZEB Design}

The literature review demonstrates some of the techniques that could be applied towards achieving near zero-energy buildings. However, these principles do not work very well in the Middle East because they ignore the effects of a very important parameter, namely the culture of the occupants.

The culture of the occupants is a main or primary pillar in the concept design of near zero-energy buildings in Middle Eastern countries, because a simple analysis of the sector of energy consumption inside residential units will show that the majority of energy consumption depends on three things: the kitchen, lighting, and the TV. According to the culture of this region in Lebanon, most families spend more than $65 \%$ of their days cooking, which means using the cooker or watching TV, resulting in the use of natural gas or electricity on the cooker and/or TV. We propose that Equation (1) states that a NZEB can be quantitatively described through an understanding of the materials, energy systems, and occupant behavior in a linear fashion.

NZEBD = Material Properties + Energy System + Culture and Social Behavior of Occupants

$$
\mathrm{NZEBD}=\mathrm{MP}+\mathrm{ES}+\mathrm{CSBO}
$$

(NZEBD) Near Zero-Energy Building Design

(NCNZEBD) New Concept of Near Zero-Energy Building Design

(MP) Material Properties (first pillar)

(ES) Energy System (second pillar)

(CSBO) Culture and Social Behavior of Occupants (third pillar)

Equations (1) and (2) demonstrate that this new concept of near zero-energy building design is based on three pillars, which are material properties (MP), energy system (ES) (including cooling/heating), and culture and social behavior of occupants (CSBO). Table 3 explains the different pillars that will directly affect designing near zero-energy buildings in Lebanon and Middle Eastern countries. In the next step, we discuss the methodology and techniques that should be applied in each pillar to achieve near zero-energy buildings in Lebanon and, more broadly, the Middle East. 
Table 3. The three pillars of a new concept of near zero-energy building design.

\begin{tabular}{ccc}
\hline \multicolumn{3}{c}{ New Concept of near Zero Energy Building Design } \\
\hline First Pillar & Second Pillar & Third Pillar \\
\hline Material Properties & Energy System & Culture and Social Behavior of Occupent \\
\hline $\begin{array}{c}\text { Definition: All materilas using in } \\
\text { construction of residential buildings }\end{array}$ & $\begin{array}{c}\text { Definition: All type of Renewable } \\
\text { Energy and Clean Energy with the } \\
\text { grid connection }\end{array}$ & $\begin{array}{c}\text { Definition: All Culture and Social Behavior } \\
\text { of Users which can effect in reducing energy } \\
\text { consumption }\end{array}$ \\
\hline $\begin{array}{c}\text { Scope: All Physical and chemistry } \\
\text { Materials properties, Passive } \\
\text { Architecture technics, Indoor } \\
\begin{array}{c}\text { Environmental Control, Intellgient } \\
\text { Features, ... etc. }\end{array}\end{array}$ & $\begin{array}{c}\text { Scope: Solar Cells on the roof or } \\
\text { on facades, Photovoltaic cells farm, } \\
\text { Wind turbine, Water turbine, } \\
\text { Geothermal, Biomass, ... etc. }\end{array}$ & $\begin{array}{c}\text { Scope: Social Studies about all habitate of } \\
\text { users and all studies that enhance the } \\
\text { awarenece of energy consumptions, .... etc }\end{array}$ \\
\hline $\begin{array}{c}\text { Objective: Reduce the internal load, } \\
\text { reduce the energy demand, reduce the } \\
\text { HVAC equipment energy } \\
\text { consumption, } \ldots \text { etc. }\end{array}$ & $\begin{array}{c}\text { Objective: Produce energy from } \\
\text { renewable source on site or offsite } \\
\text { delivered from nearby. }\end{array}$ & $\begin{array}{c}\text { Objective: Reduce the energy consumption } \\
\text { through change the behavior of users with } \\
\text { Awareness campaign about the benefit of } \\
\text { decresse energy demand. }\end{array}$ \\
\hline
\end{tabular}

\subsection{Methods to Be Applied in the Design Process}

The main methodology for achieving near zero-energy buildings should involve three phases:

- First phase: This stage will establish a framework or guidelines for selecting materials that should be used in the construction process. These materials should enhance the indoor environmental controls through their physical and chemical properties, such as advanced materials, nanomaterials, zero-carbon materials, etc.

- Second phase: This stage will include an analysis of energy consumption systems for regular homes (the area and type will be selected for specific reasons according to home-building and will be restricted to Lebanon). An energy-generation system by renewable energy sources (solar, wind, geothermal, biomass, etc.) will be modeled for these residential structures.

- Third phase: This stage of the proposed research will collect social and cultural data through questionnaires to measure the energy awareness of the occupants. It will increase their level of knowledge of using different options and solutions that will decrease the amount of energy consumption over the years. It will consider the long-term benefits and difficulties faced through the implementation of this idea. This survey will have several sections of questions (the types of appliances that occupants used in their house, investigation of materials used in their building, the monthly electricity bill they pay, brief description of their daily activity inside their house, etc.). After analyzing this data, a workshop of awareness for the target group will be adequate to increase their level of knowledge about how they can decrease their energy consumption.

\subsection{Material Properties}

The main objective of this pillar is to ensure the control of the indoor environment and to provide comfort and a protective indoor space to enhance the quality of life inside these spaces for occupants. From Table 2, the scope of this pillar has three categories.

\subsubsection{Physical and Chemical Material Properties}

In this category, the architect should consider the newest materials with good physical and chemical properties that provide high efficiency functions (high performance) and minimal dimensions, and have eco-friendly materials in mind when selecting the materials to build with. One of these materials could be nanomaterials, which have many advantages, such as more efficiency in their functions and thin dimensions, which means that they would save space indoors. Saving space indoors is the marketing equivalent of saving money. Some examples of nanomaterials that can positively affect indoor environment control are: 


\section{- Thermal insulation:}

- $\quad$ Thermal insulation: Vacuum insulation panels (VIPs)

- Thermal insulation: Aerogel

- $\quad$ Temperature regulation: Phase-change materials (PCMs)

- Window materials:

- UV protection

- $\quad$ Solar protection (smart windows)

- Coating materials:

- $\quad$ Self-cleaning: Lotus effect

- $\quad$ Self-cleaning: Photocatalysis

- $\quad$ Easy to clean (ETC)

- $\quad$ Air-purifying

- $\quad$ Anti-graffiti

- $\quad$ Anti-reflective

\subsubsection{The Role of Intelligent Features in Passive Architecture Design}

The main role of intelligent devices in a NZEB is to optimize the efficiency of different types of electric systems, such as the lighting system, Heating, ventilation, and air conditioning (HVAC) system, etc. This function can be carried out by using:

- A "brain": This is the controller of the whole system, where the programming and control of devices originates. It is similar to a building management system (BMS), typically used in commercial construction. These can be quite complex computer-controlled systems with extensive networks. In a residential setting, we typically think of a thermostat as the "BMS" for the HVAC system. More sophisticated residential control systems are available.

- Sensors: These are the feedback elements of a control system. For example, a temperature sensor coupled with a solar radiation sensor could be used to control the opening or closing of insulated window coverings. More simply, an interior temperature sensor could be used to control the operation of a ventilation fan.

Any intelligent building, commercial or residential, should have a BMS, which is like a brain, and building automation system BAS, which is like hands. Further, each intelligent building should have outdoor sensors and indoor sensors, and all can be connected and automated by a mobile application [17].

\subsection{Energy Systems}

The main objective of this pillar is to produce clean and renewable energy from various resources, such as the sun, wind, water, geothermal, biomass, etc., as an energy-generation system. Again, from Table 3, the scope of this pillar is to support the home with different categories of renewable energy supply to achieve sufficient energy as needed in the home. The categories of renewable energy will be evaluated through BIM (Building Information Model) by adding plugging to calculate the energy consumption system (for different appliances inside the home). This will be shown in future research.

\subsubsection{Photovoltaic Cells on the Roof/South Elevation}

The first generation of solar cells was based on a single crystalline semiconductor wafer. The second generation utilizes an inorganic thin-film structure in cell assembly. They are cheaper to produce, but the efficiency of less than $14 \%$ of amorphous thin-film solar cells is lower than that 
of the single-junction crystalline solar cells from the first generation, which can be as high as $27 \%$. Theoretically, single-junction cells should be able to exhibit a maximum efficiency of $\pm 33 \%$, a limit set by Shockley-Queisser thermodynamics. Thus, a new solar cell technology is required to achieve efficiencies greater than $33 \%$, with lower production costs. This is made possible by the third generation of solar cells [18-20].

\subsubsection{Solar Thermal System}

Solar thermal energy can be used to provide hot water in homes and public places. Polymer nanocolors can be used for the thermal and anti-corrosion insulation of walls, ceilings, installations, pipes, and tanks. This paint can be applied using very simple methods, such as spraying, rolling, or brushing, and provides thermal insulation. Nanocolor insulation is used in the industrial and construction sectors in the form of a thin (micron size) layer of thermal insulation.

Solar collector systems can be categorized as (a) stationary or (b) concentrating solar collectors. The difference between stationary and concentrating solar collectors is that stationary collectors have the same area for intercepting and absorbing solar light intensity, whereas the concentrating collectors have reflecting surfaces to intercept and focus the solar light intensity to a smaller (focal) area for higher working fluid temperature generation. The stationary solar collectors are best suited for the generation of heat on a smaller scale, whereas the concentrating solar collector technology is capable of producing electricity on a large scale (Table 4) [21].

Table 4. Different types of solar thermal collectors. Reference: [21].

\begin{tabular}{ccccc}
\hline Category & $\begin{array}{c}\text { Sun Tracking } \\
\text { Motion }\end{array}$ & Type & $\begin{array}{c}\text { Concentration } \\
\text { Ratio Range }\end{array}$ & $\begin{array}{c}\text { Possible Operating } \\
\text { Temperature Range }\end{array}$ \\
\hline $\begin{array}{c}\text { Stationary solar } \\
\text { thermal collectors }\end{array}$ & Stationary & Flat plate collector & 1 & $30-80{ }^{\circ} \mathrm{C}$ \\
\hline & Evacuated tube collector & 1 & $50-200{ }^{\circ} \mathrm{C}$ \\
\hline $\begin{array}{c}\text { Concentrating } \\
\text { solar thermal } \\
\text { collectors }\end{array}$ & Single axis & Linear Fresnel reflector & $10-40$ & $60-250{ }^{\circ} \mathrm{C}$ \\
\hline & Parabolic trough \\
collector & $10-85$ & $60-400^{\circ} \mathrm{C}$ \\
\hline & Double axis & Parabolic dish system & $600-2000$ & $100-1500^{\circ} \mathrm{C}$ \\
\hline & Heliostat field system & $300-1500$ & $150-2000{ }^{\circ} \mathrm{C}$ \\
\hline
\end{tabular}

\subsubsection{Wind Turbines}

As governments strategize to solve their electricity supply issues, they should encourage investment in wind turbines throughout the country to increase the shift to clean electricity generators, which reflect on reducing greenhouse gases and produce clean energy for the housing sector. A wind turbine is a machine that uses vanes called sails or blades to convert wind energy into rotational energy and then channel it through a geared transmission to drive an electrical generator. Wind turbines are used to produce electricity. Most wind turbines can be installed on wind farms together to produce electricity. Good locations for wind farms are often found over windy hilltops, on open plains, and on beaches [22].

\subsubsection{Energy-Efficient Appliances}

A study was conducted to establish the basic characteristics of Lebanese household appliances and Lebanese householders' understanding and willingness to move towards more energy-efficient choices [23]. In their survey, a preliminary list of electrical appliances was developed and about 630 respondents were asked about ownership, usage patterns, purchase costs, and replacement rates, details of which are listed in Table 5 below [23]. 
Table 5. Select household appliance characteristics. Reference: [23].

\begin{tabular}{ccccccc}
\hline Appliance & $\begin{array}{c}\text { \% of } \\
\text { Respondents } \\
\text { Who Own the } \\
\text { Appliance }\end{array}$ & $\begin{array}{c}\text { Average } \\
\text { Number of } \\
\text { Items }\end{array}$ & $\begin{array}{c}\text { Most } \\
\text { Purchased } \\
\text { Type }\end{array}$ & $\begin{array}{c}\text { Average } \\
\text { Price at } \\
\text { Purchase }\end{array}$ & Average Use & $\begin{array}{c}\text { Average } \\
\text { Replacement } \\
\text { Rate }\end{array}$ \\
\hline Refrigerator & $100 \%$ & 1 & - & $\$ 1,202$ & - & Every 10 years \\
\hline Light bulbs & $100 \%$ & 20 & LED & $\$ 12$ & - & Every 8 months \\
\hline Microwave & $77 \%$ & 1 & - & $\$ 160$ & 3 times/day & Every 5 years \\
\hline Oven & $100 \%$ & 1 & Gas & $\$ 555$ & 3 times/day & Every 8 years \\
\hline $\begin{array}{c}\text { Clothes washing } \\
\text { machine }\end{array}$ & $100 \%$ & 1 & $7-9$ Kgs & $\$ 630$ & 4 times/week & Every 7 years \\
\hline $\begin{array}{c}\text { Clothes dryer } \\
\text { machine }\end{array}$ & $22 \%$ & 1 & $7-9$ Kgs & $\$ 752$ & 3 times/week & Every 7 years \\
\hline Split AC Units & $87 \%$ & 3 & $12,000 \mathrm{BTU}$ & $\$ 455$ & - & Every 7.5 years \\
\hline Fan & $84 \%$ & 2 & - & $\$ 51$ & $5.5 \mathrm{~h} /$ day & Every 3.5 years \\
\hline Heating & $92 \%$ & 1 & $\begin{array}{c}\text { Electric } \\
\text { heater } 12,000\end{array}$ & $\$ 295$ & $5.5 \mathrm{~h} /$ day & Every 6 years \\
\hline Computer & $77 \%$ & 1 & Laptop & $\$ 931$ & $5 \mathrm{~h} /$ day at & Every 3.5 years \\
\hline TV & $100 \%$ & 3 & $32^{\prime}-40 \prime$ & $\$ 868$ & $5 \mathrm{~h} /$ day & Every 4 years \\
\hline Dish Washer & $4 \%$ & 1 & - & $\$ 923$ & 2 times/day & Every 6.5 years \\
\hline
\end{tabular}

The home appliances used overwhelmingly by all respondents were refrigerators, light bulbs, ovens, washing machines, and televisions. Large products (such as refrigerators, washing machines, etc.) have a relatively long life before needing replacement [23]. The results of other studies showed that the potential for electricity savings would be improved by $20 \%$ to $27.4 \%$ in the residential sector by replacing existing appliances with energy-efficient household appliances [15-25].

Our proposed research will concentrate on the five appliances that make up a significant proportion of the electricity used in households from that study.

The selected appliances will be:

- Washing machines

- Air conditioners

- Televisions

- Light bulbs

- $\quad$ Refrigerators

\section{Occupant Behavior in Arab Countries}

Throughout the world, television screen sizes are increasingly becoming larger, resulting in the use of more resources. If a household that has yet to buy a new television today buys a television of the same size as 10 years ago, instead of the average size of today, they could save $50 \mathrm{~W}$ or about $47 \%$ of the energy to run their television when it is on. A washing machine's comparable saving is much lower-just $25 \mathrm{Wh}$ per load or $5 \%$ of the power used per charge. This is because washing machines have not had the same increase in size over time. For refrigerators, if a household that needed to replace its refrigerator purchased the same size as it did 10 years ago, they could save $14 \mathrm{kWh} / \mathrm{year}$ or $9.5 \%$ of the annual energy consumption of the refrigerator.

On the other hand, this work attempted to estimate potential savings by changing the way households use appliances where they have more control over how they use them-entertainment tools, washing appliances, and some types of lighting. The studies found strong connections for these devices between demographic factors (such as the number of people in a household) and energy usage. This could save an average of 330-445 kWh/year per house for lighting, audio-visual facilities, tumble dryers, and IT devices. 
Based on the 2013 report by Jason Palmer and his team, nearly 80 of the 250 households in the sample left some lights on overnight, using an average of $11.8 \mathrm{~W}$ for each household, equivalent to 23-37 kWh/year. If 1,000,000 (one million) households were to be persuaded to switch off all lights overnight, this would save 9-14.5 MW or 23-37 GWh a year. For more than one hour per day, at least 18 households left appliances on in empty rooms. These households seem to waste $62-250 \mathrm{kWh}$ per year each, and when not in use, TVs and computers are the most common devices left on. Looking at all households, we estimate that switching off unused appliances would result in typical savings of 10 to $44 \mathrm{kWh}$ per year per household.

As shown in Figure 7, a lot of attention is paid to the environment, with about $81 \%$ of respondents suggesting that they discuss and/or learn about environmental issues "often", "sometimes", and "very often". The reason for this finding is that solid waste management in Lebanon captured Lebanese media and people's attention during the survey period. Around $60 \%$ of respondents do not speak or read around energy efficiency in home appliances [15-25].

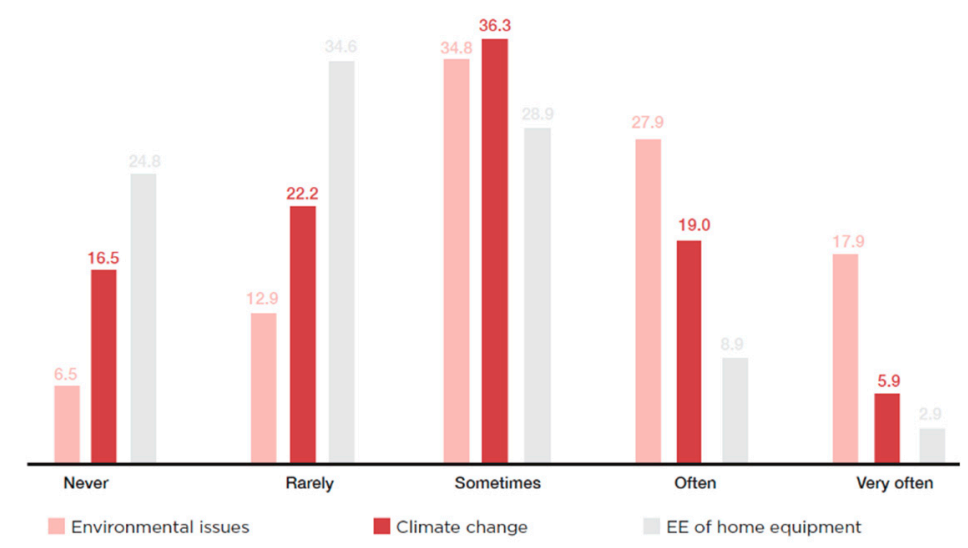

Figure 7. Statistic diagram awareness of "environmental issues", "climate change", and "energy efficiency" in household appliances (\%). Reference: [23].

\section{Proposed Research Outcomes}

Based on what has been presented, the following framework (Table 6.) will be verified as a result of the proposed research work. When completed, this guide will provide the following for the architect who wants to build near zero-energy buildings in Lebanon or in other Middle Eastern countries:

Table 6. Framework for near zero-energy building design.

\begin{tabular}{|c|c|}
\hline \multicolumn{2}{|r|}{ Framework for Near Zero-Energy Building Design } \\
\hline \multirow{3}{*}{ Material Properties } & Physical and chemical material properties \\
\hline & The role of passive architecture techniques \\
\hline & Intelligent features \\
\hline \multirow{3}{*}{ Energy System } & Energy consumption system (DHW, HVAC, lighting, other electricity power) \\
\hline & Energy-generation system (solar PV system, solar thermal system, wind turbine) \\
\hline & Energy-efficient appliances \\
\hline \multirow{2}{*}{$\begin{array}{l}\text { Culture and Social Behavior of } \\
\text { Occupant }\end{array}$} & $\begin{array}{c}\text { Awareness of environmental issues, climate change and energy efficiency } \\
\text { associated with the use of household appliances }\end{array}$ \\
\hline & Changing social behavior of occupant \\
\hline
\end{tabular}

\section{Conclusions}

We have proposed that there is a quantifiable relationship between three pillars-material properties, energy systems, and the culture and social behavior of occupants-that work together 
towards a new concept of near zero-energy buildings in Lebanon. The new concept stands on the emerging relationship between passive architecture techniques, material properties, and intelligent technologies to develop a framework for the functional improvement for near zero-energy building design in Lebanon and Arab countries. The main difference between near zero-energy building design in Europe and the Middle East is the pillar "culture and social behavior of occupants", which plays a huge role in this equation because energy is wasted according to the occupants' behavior and their culture.

The proposed framework will present a solid base on which to build upon for future research in sustainable development strategies and to improve functional building in countries facing environmental crises, while working towards near zero-energy building design in Arab regions. The framework will help and guide the architect to build an environmentally friendly home in order to mitigate environmental problems, such as global warming and climate change, using affordable architecture techniques. All this work cannot be carried out without increasing the awareness in communities about the role of occupants' behavior in decreasing the energy waste inside buildings. This research will be the first step for several future research studies that will conduct development strategies for functional improvement in new building design and existing buildings.

Funding: This research received no external funding.

Conflicts of Interest: The authors declare no conflict of interest.

\section{References}

1. Foulds, C. Practices and Technological Change: The Unintended Consequences of Low Energy Dwelling Design. Ph.D. Thesis, School of Environmental Sciences, University of East Anglia, Norwich, UK, 2013.

2. Attia, S. Net Zero Energy Buildings (NZEB): Concepts, Frameworks and Roadmaps for Project Analysis and Implementation; Elsevier: Amsterdam, The Netherland, 2018.

3. Salem, R.; Bahadori-Jahromi, A.; Mylona, A. Investigating the impacts of a changing climate on the risk of overheating and energy performance for a UK retirement village adapted to the nZEB standards. Build. Serv. Eng. Res. Technol. 2019, 40, 470-491. [CrossRef]

4. Max, J.; Olivia, B.; Yann, V.; Joanne, A. 2010/31/EU of the European Parliament and of the Council of 19 May 2010 on the Energy Performance of Buildings; Official Journal of the European Union: Luxembourg, 2010; pp. 1-138. [CrossRef]

5. Committee on Climate Change. The Fifth Carbon Budget. Available online: www.theccc.org.uk/wpcontent/uploads/2015/11/Committee-on-Climate-Change-Fifth-Carbon-Budget-Report.pdf (accessed on 14 February 2020).

6. Salem, R.; Ali, B.-J.; Anastasia, M.; Paulina, G.; Cook, D. Retrofit of a UK residential property to achieve nearly zero energy building standard. Adv. Environ. Res. 2017, 7, 223-241.

7. Hirota, A.; Otsuka, A.; Yoshida, T. Energy Saving Technologies in Home Appliances. Available online: http://www.hitachi.com/rev/pdf/2008/r2008_05_109.pdf (accessed on 20 February 2020).

8. Korbee, H.; Smolders, B.; Stofberg, F. Millieu Voorop Bij Uitwerking Van Een Global Bestemmings Plan TH Delft, Afd. Bouwkund; Bouwkund: Delft, The Netherlands, 1979; pp. 22-27.

9. da Graça, G.C.; Augusto, A.; Lerer, M.M. Solar powered net zero energy houses for southern Europe: Feasibility study. Sol. Energy 2012, 86, 634-646. [CrossRef]

10. Peacock, A.D.; Jenkins, D.P.; Kane, D. Investigating the potential of overheating in UK dwellings as a consequence of extant climate change. Energy Policy 2010, 38, 3277-3288. [CrossRef]

11. Roaf, S.; Crichton, D.; Nicol, F. Adapting buildings and cities for climate change. In A 21st Century Survival Guide; Archit Press: Hudson, NY, USA, 2009; Volume 2, pp. 15-21.

12. Pana, E. Summertime temperatures and overheating risk: Does orientation affect comfort in bedrooms in the UK context? In Proceedings of the 3rd Conference: People and Buildings, London, UK, 20 September 2013; pp. 1-6.

13. Baborska-Naroz_ny, M.; Stevenso, F.; GrudzinÅL ska, M. Overheating in retrofitted flats: Occupant practices, learning and interventions. Build. Res. Inf. 2016, 45, 40-59. [CrossRef] 
14. Salem, R.; Bahadori-Jahromi, A.; Mylona, A.; Paulina, G.; Darren, C. Investigating the potential impact of energy-efficient measures for retrofitting existing UK hotels to reach the nearly zero energy building (nZEB) standard. Energy Effic. 2019, 12, 1577. [CrossRef]

15. Jason, P.; Nicola, T.; Tom, K.; Steven, F.; Mark, H.; Peter, P.; Jacob, Y.; David, K.; Daniel, G. Electrical Appliances at Home: Tuning in to Energy Saving; This second research report written by Cambridge Architectural Research; Loughborough University: Loughborough, UK, 2013.

16. Huw, H. 101 Rules of Thumb for Low Energy Architecture; RIBA Publishing: London, UK, 2012; pp. $180-189$.

17. Omar, O. Intelligent building, definitions, factors and evaluation criteria of selection. Alex. Eng. J. 2018, 57, 2903-2910. [CrossRef]

18. Omar, O. Nanoarchitecture and Global Warming. Ph.D. Thesis, Alexandria University, Alexandria, Egypt, 2012.

19. Shockley, W.; Queisser, H.J. Detailed Balance Limit of Efficiency of P-N Junction Solar Cells. J. Appl. Phys. 1961, 32, 510-519. [CrossRef]

20. Green, M.A. Prospects for Photovoltaic Efficiency Enhancement Using Low-Dimensional Structures. Nanotechnology 2000, 11, 401. [CrossRef]

21. Dincer, I.; Ratlamwala, T.A.H. Solar Thermal Power Systems. Available online: https://www.researchgate. net/publication/271015246_Solar_Thermal_Power_Systems (accessed on 20 February 2020).

22. Vini, M.; Shah, P.K.C.; Dilip, H.; Rudra, N.; Manjurali, I.; Vijendra, M.; Vipul, D. The Concept of Zero Energy Buildings (ZEB)-A Literature Study. Int. J. Innov. Res. Technol. 2019, 6, 131-132.

23. Harajli, H.; Chalak, A. Energy Efficient Home Appliances Perspectives from Lebanese Consumers. Available online: https:/www.undp.org/content/dam/lebanon/docs/Energy\%20and\%20Environment/Publications/ CEDRO\%20_\%20Energy\%20Efficient\%20Home\%20Appliances.pdf (accessed on 20 February 2020).

24. Claudia, M.; Ghisi, E. Assessment of the Impact of Energy-Efficient Household Appliances on the Electricity Consumption in the Residential Sector of Brazil. In Proceedings of the World Energy Council Conference, Montreal, QC, Canada, 12-16 September 2010.

25. Raue, A.K.; Kurvers, S.R.; van der Linden, A.C.; Boerstra, A.C.; Plokker, W. Dutch Thermal Comfort Guidelines: From Weighted Temperature Exceeding Hours Towards Adaptive Temperature Limits. In Proceedings of the Comfort and Energy Use in Buildings: Getting Them Right, Windsor, UK, 27-30 April 2006; pp. 1-16.

(C) 2020 by the author. Licensee MDPI, Basel, Switzerland. This article is an open access article distributed under the terms and conditions of the Creative Commons Attribution (CC BY) license (http://creativecommons.org/licenses/by/4.0/). 